\title{
Impact of «One Belt, One Road» initiatives to the economy of Central Asian countries
}

Imomov Imomnazar

Hiroshima University, Japan

\section{Keywords}

One Belt-One Road, Central Asia, Investment, Infrastructure, Trade

\begin{abstract}
"One Belt - One Road" - the Chinese initiative to create the Silk Road Economic Belt (SREB) and the Maritime Silk Road (MSR) was first announced by the Chairman of the People Republic of China Xi Jinping during his official visit to Kazakhstan and Indonesia in 2013.

The main goal of "One Belt - One Road" initiative lies in the exploration, formation, and promotion of a new model for international cooperation and development through strengthening of current regional bilateral and multilateral mechanism and structures of collaboration with the participation of China based on maintenance and development of the spirit Ancient Silk Road.

Central Asia for many centuries was a dynamic center linking regional and international communities via the historic Silk Road. Nowadays Central Asia is tremendously important for China for several reasons. Firstly, Central Asia is the gate for China to the West. All land routes which going from China to Europe or South Asia passing through Central Asian countries. Secondly, three of Central Asian countries share a border with China. There are traditional -cultural links between peoples on both sides of the border. Lastly, Central Asian countries are rich in natural resources especially in hydrocarbon reserves which is more important for the lifeline of the Chinese economy. Connectivity and trade with Central Asia are considered necessary for development and stability of Chinese foreign policy.
\end{abstract}

Corresponding author: Imomov Imomnazar

Email address for corresponding author: imomnazartajdip@gmail.com

First submission received: 20 $0^{\text {th }}$ March 2018

Revised submission received: $20^{\text {th }}$ June 2018

Accepted: $26^{\text {th }}$ June 2018

\section{Introduction}

Nowadays, China is experiencing an economic growth very fast in world history. Still, it's unclear that with which model Chinese are developing and going ahead. It's the daily question between scholars and analytics. So, "One Belt - One Road" is supposed to be an answer for the future of Chinese long-term development goals.

Chinese President Xi Jinping launched the "One Belt - One Road" (OBOR) initiative in Nazarbayev University, in Kazakhstan 2013. One of the biggest stories in Asian business is China's One Belt, One Road initiative, an economic and diplomatic project that could transform trade. The implementation of Chinese initiative should help increase trade and investment in the countries along the Belt and Road. The Belt and Road run through the continents of Asia, Europe, and Africa, connecting the East Asia economic circle at one hand and developed European economic circle at the other, and encompassing countries with huge potential for economic development. "One Belt - One Road" is the first ambitions and megaproject which connecting the people of Asia to the Europe and Africa within economic trade tradition and cultural ties which the world history never experienced it before. "We can Use the innovative model of collabo- 
ration to build the New Silk Road economic belt together so that we forge closer economic ties between Europe and Asia and deepen our mutual collaboration to experience even greater development. This great project benefits everyone along this road. (Xi Jinping's speech at Nazarbayev University, Astana 2013)". According to the official data, more than 65 countries of the world are involved in «One Belt - One Road» project including new economy, developing and developed countries. «One Belt - One Road» covers 30\% of global economic capacity, $55 \%$ of the world GDP, about $70 \%$ of the world population and about $75 \%$ of the world global energy resources.

One Belt - One Road's map

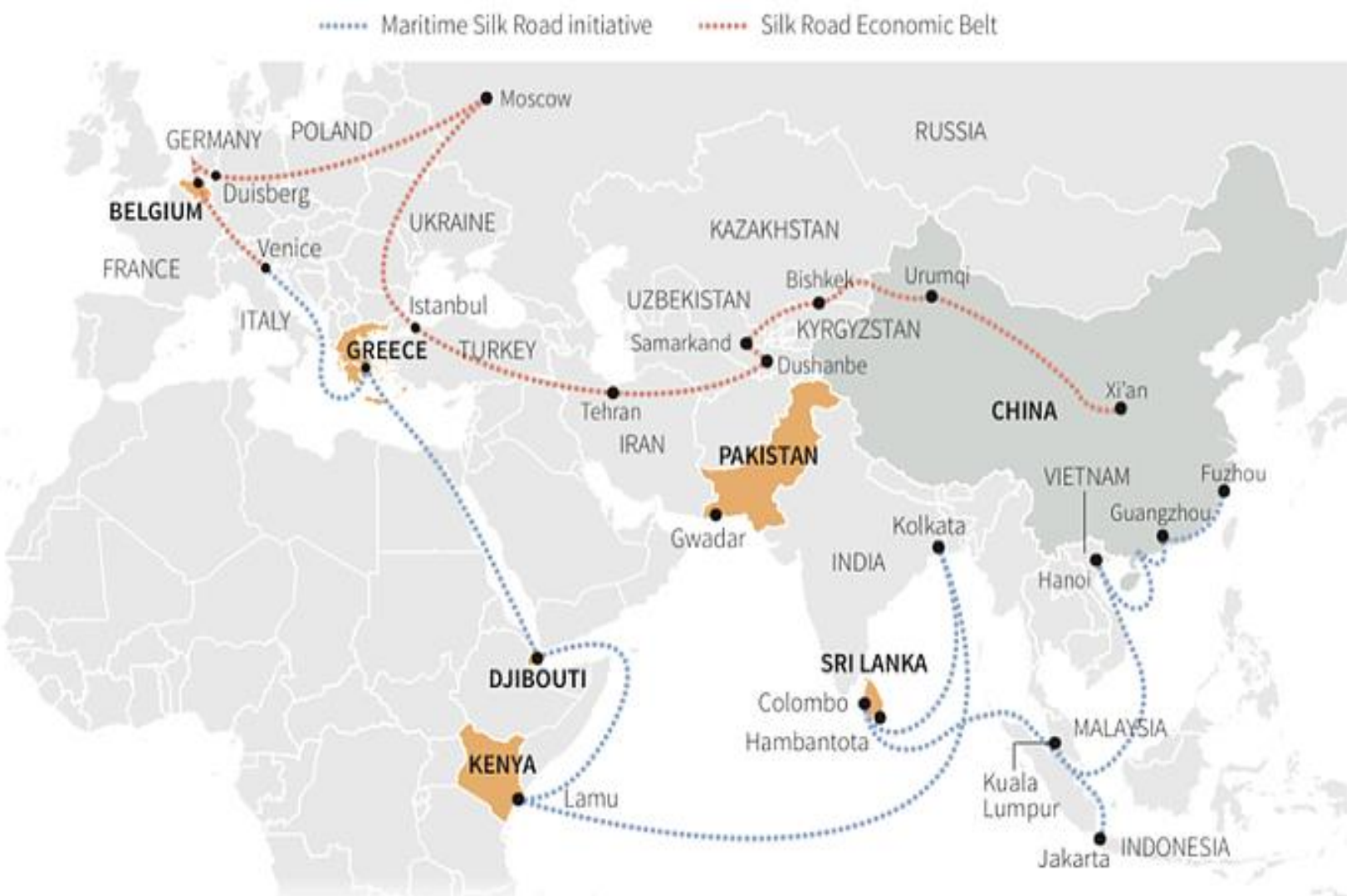

\section{Source: Reuters}

During four year of implementation, the project has received the remarkable result. The Chines high-level official visits more than 25 countries, participating in the dialogue and strengthening bilateral relations. Currently, more than 30 countries signed an agreement on "One Belt - One Road" project with China. In May 2017 in Beijing held an international summit by "One Belt - One Road" in which the heads of 30 states and governments as well as 1200 delegation from different countries of Asia, Europe, North America, Latin America and Africa participated. The parties discussed the real ways of promoting project "One Belt - One Road "One Belt - One Road" and shared the mutual benefit from international cooperation and strengthening international cooperation. Summit helped for signing contracts for the implemen- 
tation of 76 major projects based on investment, infrastructure, political communication, barrier-free trade, financial integration and ensuring the connection between people.

According to the Ministry of Commerce of China, direct investment from China to the countries which involved in «One Belt - One Road» (almost 65 countries) increased sharply from \$ 200 million in 2003 to 14.53 billion US dollars in 2016. After announcing «One Belt - One Road» initiative signed contracts for more than 126,03 billion dollars. This mega-investment and ambitious project will have the significant impact on the nations through which it crosses.

At the "One Belt - One Road" Summit which held in Beijing, Xi Jinping mentioned that over the past three years, Chinese investments in the countries that joined the "One Belt - One Road" amounted to about $\$ 50$ billion. In the coming years, it is planned to increase this amount to $\$ 150$ billion. "One Belt One Road" contains about 900 different infrastructure projects including roads, railways, ports, power stations, and bridges in more than 60 countries. For the implementation of this projects, expert is estimating amounts from $\$ 2$ to $\$ 3.5$ trillion.

Everyone is thinking that nowadays, for many countries located on the ancient Silk Road, particularly landlocked Central Asia, a historic «One Belt - One Road» trade system appears to be the only alternative for their prosperity and development. Despite increasing economic, political and cultural cooperation between China and Central Asia, the role of Central Asian countries in this project is still under consideration and under-researched. The following questions remain unaddressed: what's the benefit of the "One Belt - One Road" project to the economy of Central Asian states? How to implement this project in the region for the stability, development, prosperity, and integration of Central Asia? What specific threats exist in the «One Belt, One Road» to the economy of Central Asia in its contemporary stage?

\section{China and Central Asia from Silk Road to "One Belt - One Road"}

Looking at the political map of the world its seems that Central Asia is in the center of the world and it has several advantages and disadvantages. Connecting one part of the world to another and being transit corridor for exporting and importing goods are the priority of locating Central Asia between the East and West. Central Asia is the place which Silk Road crosses it, it is the place that Alexander Great died, where Marco Polo searched for silk routes to Venice, and where British and Russian Empire had a Great Game. In a fact, west for most Chinese scholars and politics was Central Asia, not the modern European West. From the period of Khan Dynasty, Central Asia was the strategic place and Chinese tried always to take have peaceful relation with the head of the Central Asian countries. These historical reasons are a reasonable scientific basis for abandoning the term "Silk Road" as a historical concept. The Silk Road was the only of shorter trade routes that connected the Chinese capital Xian with various trading centers in Central Asia, including, Samarkand and Bukhara. These centers related to other points like India, Iran, Middle East, and through them - with Europe.

Chinese "One Belt - One Road" project directly linked its initiative with the legacy of the ancient "Silk Road" and presented it as a project based on equality and mutual benefit, mutual open-mindedness and the sharing of knowledge culture and tradition from each other. But the goal of the "One Belt - One Road" initiative is not only the exchange of goods, services and ideas on equal terms. It is about creating new markets and routes for Chinese goods in Asia, in part because of a falling demand for them in Europe and the US.

Beijing's influence is growing fast day by day in the region. China's desire to engage in active economic interaction, the willingness to invest impressive amounts of money in the implementation of projects which its vital necessary for Central Asian countries. After getting independence Central Asian countries in 1991 and appearing several independence states in the political map, China changed its geopolitical position. So, Central Asia was one the priority in the foreign policy of China. Countries in the region 
like Kazakhstan, Kyrgyzstan, Tajikistan, Turkmenistan, and Uzbekistan are rich in natural resources. The importance of the region as a strategic partner and market for the Chinese economy has been preserved till nowadays.

A new factor in Beijing's policy towards Central Asia was the firm consolidation of the need to develop the western regions of the country on the agenda of China's domestic policy, as China's regional dynamics still show considerable imbalances. The western regions of China are more connected with Central Asia. Thus, almost one-third of the total trade of the Xinjiang Uygur Autonomous Region of China today is going to Central Asia.

The actual issue for China is cooperating with the Central Asian states in fighting against terrorism, extremism and maintaining regional stability in recent years. The Chinese authorities are not interested in activating the Islamists and in their own territory - in Xinjiang Uygur Autonomous Region. The issues of combating terrorism and maintaining regional stability China and Central Asian states today decide both in bilateral format and through cooperation within the Shanghai Cooperation Organization. The loans play a major role in ensuring the Chinese economic penetration into Central Asia. They mean financing projects at a relatively low-interest rate, but the condition of such loans is the use of Chinese materials, equipment, or labor in the performance of work. It also practices the transfer of shares in the business, the application of production sharing agreements. These practices make it possible to maximize the use of Chinese production resources, and the transfer of shares in business leads to a gradual expansion of economic presence sectors of the economies of Central Asia. Investment is critically important for the Central Asian states to overcome geographic isolation from the seas, which greatly increases their transport costs and its limiting factor in the trade.

The particularity of the economic interaction of the Central Asian countries with China in recent years has been the alignment of domestic economic development programs of these states with the interests and strategy of Beijing. This is done to maximize the use of opportunities to attract Chinese financial resources. The financial component of the project is based on the funds of the Silk Road Fund with the amount of $\$ 50$ billion and the Asian Bank for Infrastructure Investments from $\$ 100$ billion. In general, China is ready to invest in "One Belt - One Road" to $\$ 1$ trillion. Till now, about $\$ 70$ billion, not including previously invested in the Central Asian region of investment in projects that will be inscribed in the "Silk Road".

\section{A close neighbor is better than a distant relative}

China always will strengthen good-neighborliness and friendship, deepen mutually beneficial cooperation in all sphere and make sure the country's neighbors will benefit more from its development. China pursues its Central Asian policy through multilateral and bilateral channels. The main multilateral instrument is the Shanghai Cooperation Organization, which opens new opportunities for developing positive relations with the countries of the region.

Bilateral relations with individual every Central Asian state are just as important as multilateral relations; the only thing is that they are more significant. The fact is that bilateral relations create conditions for setting and resolving the whole range of issues. It is very important that in relations with Central Asia China find the right balance in the development of multilateral and bilateral relations. Both have special functions and characteristics the most interesting point is that when bilateral and multilateral relations mutually complement each other.

China is a crucial partner of the Central Asian countries in ensuring the security of borders and regional security. The security of border with the three Central Asian countries like Kazakhstan, Kirgizstan, and Tajikistan are vital for everyone. 
There is no any desire by the Chinese side to establish hegemony or control the region, it does not threaten the small countries, but consider them and cooperate with them as equals, it does not interfere in their internal affairs and is always ready to resolve all issues through negotiations and in the spirit of justice. This kind of foreign policy and diplomacy helped China create a positive image among Central Asian countries.

Kazakhstan is China's largest economic and trading partner in Central Asia. China and Kazakhstan have not only laid a compact basis for bilateral relations but are also working to create a reliable political, economic and strategic framework for further cooperation. Comparing to the other One Belt One Road countries, Kazakhstan is strategically positioned as a portal of China to Europe common border in Khorgos to the western shores of the Caspian Sea in Aktau. In 2015, Kazakhstan and China reached an agreement on the integration of "One Belt - One Road" and the new economic policy of Kazakhstan "Nurly Zhol- Light Road". Four priority directions of the strategic cutting of "One Belt - One Road" and "Nurly Zhol" are defined: the development of bilateral trade, the accelerated expansion, and modernization of the infrastructure, the development of cooperation in the sphere of production activities and the deepening of cooperation in the financial sphere.

One Belt One Road project is strategic objectives of the Kyrgyz Republic in terms of infrastructure, development and investment attraction. China is very interested in building a railway connection with Uzbekistan through Kyrgyzstan. In addition to exporting Chinese goods to local markets, it is planned to use it for imports of raw materials to China. In some alternatives of the project, the road connects China through Kyrgyzstan not only with Uzbekistan but also with Tajikistan, Afghanistan, Iran, and Turkey, up to the connection with the European railway network.

Tajikistan has good relations with China, there are no any significant contradictions in their relations. China is a strategic partner of Tajikistan. Strengthening and developing bilateral relations and cooperation with this country is one of the priorities of Tajikistan's foreign policy. The volume of bilateral trade between China and Tajikistan is satisfactorily growing. The Government of Tajikistan intends to steadily increase its efforts to further expand and deepen trade and economic cooperation, considering favorable conditions for geographical closeness and economic complementarity. In September 2014 signed Memorandum between the National Development and Reform Commission (NDRC) of the People Republic of China and the Ministry of Economic Development and Trade of the Republic Tajikistan which it is focusing in on the integration of the country's development plans with the implementation of the One Belt One Road initiative as an important chance for the economic development of the country. Tajikistan was one of the first countries which sighed Memorandum of understanding on One Belt One Road Project with China. China has invested in the repair and reconstruction of several important highways, which it's consider as important for both sides. Chinese company of TBEA took part in the construction of a unified energy network of the Republic and the establishment of a Cogeneration plant in Dushanbe. China is primarily investing in the extraction of natural resources. One of the first notable presence of Chinese investments in the Zarafshan joint venture for the extraction and processing of gold. In addition, a decision was made to build an industrial town, of which 500 million dollars were allocated. and which should include the construction of factories to produce pyrotechnics, lead, batteries, and cement.

Tajikistan and China are actively cooperating on the world stage, within the Shanghai Cooperation Organization. The two countries have similar positions in many international and regional issues.

Turkmenistan is standing apart in Central Asia. It adheres neutrality in foreign policy, and no willingness to join any regional organizations, including the Shanghai Cooperation Organization, and cooperating with all countries from a distance. Nevertheless, China has good, friendly relations with Turkmenistan. As Turkmenistan is rich in natural resources, especially natural gas can be accessed from Cen- 
tral Asia to West Asia, the Middle East, and Europe which makes Turkmenistan very significant in terms of energy and transport. Therefore, China seeks to develop good relations with Turkmenistan, especially in the field of trade and energy resources.

The great opportunity is related to the opening of the International Port in Turkmenbashi. With the implementation of this project, it will be possible to send cargo via the international port of Turkmenbashi from China, Japan, Korea, as well as from Central Asia, to the Iranian port of or Azerbaijan. Modern equipment was used in the construction of several infrastructure facilities, two railway stations, as well as an oil terminal at the customs post-Imamnazar. All this has conditioned the compliance of the first phase of the international railroad Turkmenistan - Afghanistan - Tajikistan with international standards which it's linking Afghanistan, Tajikistan and Turkmenistan easy access to China, India, and Pakistan.

Uzbekistan differs from the others Central Asian countries because of there is no common border with China, and it reduces the possibility of conflicts in matters of the border, water resources or other critical issues. From the point of transit potential Uzbekistan has a great advantage as a position in the center of the region and a developed network of railways and highways.

China and Uzbekistan have no serious political differences, and they managed to bring their relationship to the level of generous partnership. Nowadays, China and Uzbekistan are striving to improve transport links. The communication between these countries goes mostly through the territory of Kazakhstan, which leads to rather high transit costs. It is assumed that if the transport problem can be solved, the volume of bilateral trade can be more and more. Energy can make a significant contribution to bilateral relations and improve the status of Uzbekistan in Chinese foreign policy. Oil and gas are the main interest of China to Uzbekistan.

If Beijing builds China-Kyrgyzstan-Uzbekistan-Turkmenistan-Iran-Persian Gulf railway corridor with the possible exit from Iran through Turkey to Europe planned by the "One Belt - One Road" this section will be its element ensuring the inclusion of Uzbekistan in the global network of logistics routes. After implementing this project, Uzbekistan will get a direct exit not only to China but also to the Middle East.

\section{Benefit and challenges of "One Belt - One Road" to Central Asia}

It is impossible to deny China's obvious interests to Central Asia. Without any doubt countries participating in the project can and should find and occupy the maximum economic and political benefits for themselves.

Central Asia located in the heart of Asia, at the crossroads of two continents, has serious chances to get maximum benefits from the implementation of the Chinese initiative of economic cooperation. Considering the absence of the access to the sea for several central Asian countries Chinese project is the best option for solving this issue. Moreover, the overland route has a great advantage over the sea route in the form of the speed of delivery of goods for example from China to Europe, the train can get in 15 days, which is twice as fast as in the sea.

Thus, Central Asia can use the opportunities and resources of the "One Belt - One Road" to actively promote domestic products to new markets - to China and other countries along the Belt, to attract investment in the development of basic sectors of the national economy, more fully implement their logistics advantages.

In Central Asia, there are some worries regarding the flow of migrants from China. Chinese companies like to use their own material for construction infrastructure their own people and bring Chinese labor to get a job done. It doesn't give people local jobs and employ local specialists. The dominance of Chinese companies in major projects in Central Asia can be challenging for the local companies. And they cannot be in a competition with the Chinese company who has a deep pocket in finance. 
Another challenge is that of increasing terrorism and extremism group which it's threatening to the Implementation of the One Belt One Road initiative. There is will be long highways, ports bridges along the Belt which unfortunately it will be the main target of these group.

\section{Conclusion}

China is trying to have a close relation with every country despite location and especially with neighbors. As the population of China is increasing rapidly so it's their policy to move the people around the world and provide them with a food job. As the Chinese initiative is still in the initial years of implementation and it has a huge impact on the Central Asian economy. New market opportunities are available along this huge initiative. The initiative is providing the chance for Central Asia to construct the road, railway, access to modern technology, transport, and logistics.

In the last 20 years, Central Asia countries have experienced rapid economic growth averaging 7 percent and investment from China increased and continued economic growth.

Step by step the character of international policy is becoming more complicated because of new rules, new actors and new competition. If the competition is totally free and it's going for the prosperity and developing of the region it will be great, never forget that behind everything is staying something different. Let's hope for the prosperity of this world and wait what will happen tomorrow. Somehow, it's impossible to predict or expect the outcome of initiative while it's going on.

\section{References}

Alexander Cooley, Russia and China in Central Asia, Norwegian Institute of Internal Affairs, 2015;

Alexander Cooley, The Emerging Political Economy of OBOR, The Challenges of Promoting Connectivity in Central Asia and Beyond, Report of The CSIS Simon Chair in Political Economy, (October 2016);

Ambassador (R) Fauzia Nasreen, The new Great Game in Central Asia: Challenges and Opportunities for Pakistan, 2016;

Andrew Chi Lok YUEN CHUK, China's Belt-Road Initiative, Business School

Briefing on China's “One Belt, One Road” Initiative - New Silk Road Initiative for Inter-Continental Growth, Law Express, (August 2015);

China's One Belt, One Road: Challenges and Opportunities, Clifford Chance

Francisco Gómez Martos, China's "One Belt, One Road Initiative": challenges and requirements for its successful implementation in Central Asia, 2017, Brussel, Belgium;

Lain, S., \& Pantucci, R. (2015, November). The Economics of the Silk Road Economic Belt. Workshop Report, London: Royal United Services Institute for Defence and Security Studies;

Liu Haiquan The Security Challenges of the "One Belt, One Road" Initiative and China's Choices;

Hongzhou, Z. (2015, May). Building the Silk Road Economic Belt, problems and priorities in Central Asia. Policy Report. Singapore: Rajaratnam School of International Studies;

M. Královičová, M. Žatko, One belt one road initiative in Central Asia: implications for competitiveness of Russian economy, August 2016;

Patrick Bessler, China's "new Silk Road": Focus on Central Asia, EU-ASIA Economic Governance Forum, Berlin;

National Development and Reform Commission, Ministry of Foreign Affairs, and Ministry of Commerce of the People's Republic of China. (2015). Vision and Actions on Jointly Building Silk Road Economic Belt and 21stCentury Maritime Silk Road.

Retrieved from http://en.ndrc.gov.cn/newsrelease/201503/t20150330_669367.html

One Belt One Road Project - Prospects for the CIS (informational and analytical note), Moscow 2016;

Peter Cai, Understanding China's Belt and Road Initiative, Law Institute for International Policy, March 2017;

Peter Wolff, China's 'Belt and Road' Initiative - Challenges and Opportunities, German Development Institute / Deutsches Institut für Entwicklungspolitik (DIE);

Prospects and challenges on China's 'one belt, one road': a risk assessment report, From the Economist Intelligence Unit; 
Raymond Mah, "One Belt, One Road: Impact and Opportunities for Asia \& Europe", MahWengKwai and Associates, August 2016;

S. Frederick Starr, Svante E. Cornell, Nicklas Norling, The EU, Central Asia, and the Development of Continental Transport and Trade, Silk Road Paper (December 2015);

Simeon Djankov and Sean Miner, China's Belt and Road Initiative Motives, Scope, and Challenges, Person Institute for International Economics, March 2016

Tajikistan, Central Asia, and One Belt One Road strategy Thomas Chan, China Business Centre, The Hong Kong Polytechnic University, (October 2015);

Thomas Zimmerman, The New Silk Roads: China, the U.S., and the Future of Central Asia, Center on International Cooperation, October 2015;

Troy Sternberg, Ariell Ahearn, and Fiona McConnell, Central Asian 'Characteristics' on China's New Silk Road: The Role of Landscape and the Politics of Infrastructure;

Vassiliy V.Korolyov, Project OBOR (One Belt One Road) as a historic challenge for Central 